\title{
UPAYA MENINGKATKAN HASIL BELAJAR IPS EKONOMI MENGGUNAKAN MODEL PEMBELAJARAN KOOPERATIF TIPE CO-OP CO-OP PADA KELAS VIII IPS-2 SMP ISLAM NURUL IHSAN PALANGKA RAYA
}

\author{
Oleh \\ Rizki Amalia*, M. Ramli**
}

\begin{abstract}
This study aims to (1) To find out how the learning activities of class VIII IPS-2 students of ISLAMIC NURUL IHSAN SMP Palangka Raya using cooperative learning models Co-op Co-op type. (2) To improve the economics social studies learning outcomes of Class VIII IPS-2 students in the Islamic Middle School of NURUL IHSAN in Palangka Raya using a cooperative learning model Co-op Co-op type. This type of research is classroom action research (CAR). The subjects of this study were all students of class VIII IPS-2SMP ISLAMIC NURUL IHSAN Palangka Raya with a total of 30 students. Data collection techniques used are observation and tests. Data analysis used is qualitative analysis and quantitative analysis. The results of this study indicate that: (1) Activity of students both during economic social studies learning using a cooperative learning model Co-op Co-op type. The first cycle scores 3 on average with good criteria. In the second cycle, the average score was 3 with good criteria. (2) There is an increase in students' economic social studies learning outcomes after using the cooperative learning model Co-op Co-op type. It can be seen from the learning outcomes of students in the initial test that they obtained an average score of 44 (below the KKM value> 70) with $23 \%$ classical completeness with the criteria not reached. Cycle I obtained an average value of 67 with $63 \%$ classical completeness with criteria not reached. Cycle II obtained an average value of 87 with $100 \%$ classical completeness with the criteria reached.
\end{abstract}

Keywords: Learning Outcomes, Social Studies, Cooperative Learning Model.

\begin{abstract}
ABSTRAK
Penelitian ini bertujuan (1) Untuk mengetahui bagaimana aktifitas belajar peserta didik kelas VIII IPS-2 SMP ISLAM NURUL IHSAN Palangka Raya dengan menggunakan model pembelajaran kooperatif tipe Co-op Co-op. (2) Untuk meningkatkan hasil belajar IPS ekonomi peserta didik Kelas VIII IPS-2 SMP ISLAM NURUL IHSAN Palangka Raya dengan menggunakan model pembelajaran kooperatif tipe Co-op Co-op. Jenis penelitian ini adalah Penelitian tindakan kelas (PTK). Subjek penelitian ini adalah seluruh peserta didik kelas VIII IPS-2SMP ISLAM NURUL IHSAN Palangka Raya dengan jumlah 30 peserta didik. Teknik pengumpulan data yang digunakan yaitu observasi dan tes. Analisis data yang digunakan yaitu analisis kualitatif dan analisis kuantitatif. Hasil penelitian ini menunjukan bahwa: (1) Aktivitas peserta didik baik pada saat pembelajaran IPS ekonomi menggunakan model pembelajaran kooperatif
\end{abstract}


tipe Co-op Co-op. Siklus I skor rata-rata 3 dengan kriteria baik. Pada siklus II mendapat skor rata-rata 3 dengan kriteria baik. (2) Ada peningkatan hasil belajar IPS ekonomi peserta didik setelah menggunakan model pembelajaran kooperatif tipe Co-op Co-op. Terlihat dari hasil belajar peserta didik pada tes awal memperoleh nilai rata-rata 44 (dibawah nilai KKM >70) dengan ketuntasan klasikal 23\% dengan kriteria tidak tercapai. Siklus I memperoleh nilai rata-rata 67 dengan ketuntasan klasikal 63\% dengan kriteria tidak tercapai. Siklus II memperoleh nilai rata-rata 87 dengan ketuntasan klasikal $100 \%$ dengan kriteria tercapai.

Kata Kunci : Hasil Belajar, IPS, Model Pembelajaran Kooperatif.

\section{PENDAHULUAN}

Sumber daya manusia merupakan salah satu faktor penentu kemajuan suatu negara, dengan sumber daya manusia yang berkualitas maka suatu negara akan mampu bersaing dengan negara-negara lainnya. Sehubung dengan hal tersebut pendidikan formal merupakan hal yang mendasar bagi peserta didik untuk dapat mengembangkan pengetahuan dan keterampilan diri dalam rangka peningkatan kualitas sumber daya manusia, maka sangat diharapakan tujuan pendidik bisa tercapai secara optimal.

Tujuan Pendidikan Nasional adalah mencerdaskan kehidupan bangsa dan mengembangkan manusia seutuhnya, yaitu manusia yang beriman dan bertaqwa terhadap Tuhan Yang Maha Esa dan berbudi pekerti luhur, memiliki pengetahuan dan keterampilan, kesehatan jasmani dan rohani, kepribadian yang mantap dan mandiri serta rasa tanggung jawab kemasyarakatan dan kebangsaan.

Sebagaimana yang tercantum dalam Undang-Undang Republik Indonesia No. 20 Tahun 2003 tentang Sistem Pendidikan Nasional Pasal 1 Ayat 1 menyatakan bahwa: Pendidikan adalah usaha sadar dan terencana untuk mewujudkan suasana belajar dan proses pembelajaran agar peserta didik secara aktif mengembangkan potensi dirinya untuk memiliki kekuatan spiritual keagamaan, pengendalian diri, kepribadian, kecerdasan, akhlak mulia, serta keterampilan yang diperlukan dalam masyarakat, bangsa dan Negara (Depdiknas, 2003:3).

Dari tujuan pendidikan nasional tersebut, jelaslah bahwa pendidikan memiliki peranan yang sangat penting dalam pembagunan nasional, yang mana manusia sebagai sumber daya yang paling utama dan untuk mencapai tujuan pendidikan yang sesungguhnya maka kita harus terus memperbaiki sistem pendidikan agar apa yang menjadi tujuan dalam pendidika nasional bisa tercapai secara optimal. Untuk mewujudkan tujuan pendidikan bukan hanya tanggung jawab pemerintahan saja, tetapi juga seluruh unsur yang terlibat yaitu keluarga, lingkungan masyrakat, dan guru. Pendidikan selalu di hadapkan pada dua tuntutan yaitu peningkatan kuantitas dan kualitas dalam hal ini pemerintah dan Depertemen Pendidikan Nasional telah mengadakan berbagai usaha untuk meningkatkan kualitas 
peserta didik, pendirian gedung sekolah, pengembangan sekolah terbuka, penambahan program pendidikan guru, pengembagan sanggar kegiatan belajar dan kursus keterampilan. Sedangkan usaha lainnya adalah revisi kurikulum, pengadaan buku-buku pendidikan, penataran guru, dan pengembangan media pendidikan.

Guru merupakan model utama dalam pendidikan yang ditiru dan merupakan ujung tombak terdepan dalam menentukan keberhasilan belajar peserta didik, dengan demikian sebagai seorang pendidik guru tidak hanya menjadi pengajar melainkan juga mampu menjadi teladan bagi peserta didik. dalam proses belajar mengajar guru mempunyai dua fungsi yaitu sebagai pengajar dan pendidik, secara otomatis guru mempunyai tanggung jawab yang besar dalam pencapaian tujuan pendidkan.

Pembelajaran adalah proses komunikasi dua arah yaitu mengajar mendidik yang dilakukan oleh pihak guru sebagai pendidik dan belajar dilakukan oleh peserta didik. Adapun beberapa pendapat para ahli tentang pengertian belajar, menurut Ngalim Purwanto (2014:85) berpendapat bahwa: belajar merupakan suatu perubahan dalam tingkah laku, dimana perubahan itu dapat mengarah kepada tingkah laku yang lebih baik, tetapi juga ada kemungkinan mengarah kepada tingkah laku yang lebih buruk.

$$
\text { Adapun pengertian belajar }
$$
menurut Susanto (2013:4) yaitu: Belajar adalah suatu aktivitas yang dilakukan seseorang dengan sengaja dalam keadaan sadar untuk memeperoleh suatu konsep, pemahaman, atau pengetahuan baru sehingga memungkinkan seseorang terjadinya perubahan perilaku yang relatif tetap baik dalam berpikir, merasa, maupun bertindak.

Dari beberapa pendapat para ahli di atas dapat di simpulkan bahwa pengertian belajar adalah suatu proses yang dilakukan oleh seseorang untuk memperoleh keterampilan, pengetahuan, sikap, melalui perubahan yang relatif tetap baik dalam berpikir, merasa, maupun bertindak. Sebagaimana pengertian belajar tentu ada tujuan belajar yang ingin dicapai setelah melalui proses pembelajaran. Setiap orang memiliki penafsiran tersendiri tentang tujuan belajar. Seperti halnya yang di kemukakkan oleh para ahli dibawah ini:

Menurut Dalyono (2010:49-51) mengatakan bahwa: Belajar adalah suatu usaha dan belajar berbagai bidang ilmu. Sedabngkn menurut Sardiman (2014:26-28) mengemukakan bahwa tujuan belajar ada tiga macam yaitu :

1. Belajar bertujuan mengadakan perubahan didalam diri.

2. Belajar bertujuan mengubah kebiasaan buruk menjadi baik.

3. Belajar bertujuan mengubah sikap dari negatif menjadi positif.

Dari pendapat di atas dapat disimpulkan bahwa tujuan belajar adalah upaya untuk mendapat pengetahuan, Penanaman konsep dan keterampilan Pembentukan sikap.

Hasil belajar merupakan hasil akhir dari proses belajar mengajar yang mana seorang guru bisa melihat apakah pembelajaran bisa diterima dan dimengerti oleh peserta didiknya dan 
untuk itu gurudi tuntut untuk memiliki keterampilan dalam proses belajar mengajar agar pembelajaran berjalan dengan menyenagkan, bisa diterima dan tujuan pendidikan bisa tercapai. Oleh sebab itu setiap guru memiliki cara-cara atau metode yang berbedabeda dalam pembelajaran namun dengan tujuan yang sama, yaitu hasil belajar peserta didik mencapai nilai kereteria ketuntasan minimum (KKM) yang mana sebagai nilai yang menjadi ukuran tercapainya suatu pembelajaran.

Ilmu pengetahuan sosial adalah ilmu yang mempelajari tentang aspekaspek yang berhubungan dengan manusia dan lingkungannya, dalam mata pelajaran IPS ekonomi yang mana berhubungan dengan perilaku manusia dalam melakukan aktivitas ekonomi yang berhubungan dengan distiribusi, produksi, dan juga komsumsi terhadap barang dan jasa. Ilmu IPS ekonomi diharapakan dapat membantu peserta didik untuk menghadapi dunia nyata yang tingkat persainganya semakin berkembanga yang mana sangat terlihat dari segi ekonominya, dengan mata Pelajaran IPS ekonomi peserta didik akan paham tentang ruang lingkup apa saja dalam ekonomi dan permasalahan- permasalahan apa saja yang ada dalam ekonomi dan bagaimana cara mengatasi permasalahan tersebut. Sehingga dalam pembelajaran IPS ekonomi perlu ditekankan sebuah proses pembelajaran secara langsung melalui pengembangan keterampilan proses dan sikap ilmiah. Maka perlu digunakan beragam metode dan model pembelajaran dalam penyampaian materi.
Materi yang akan diajarkan di kelas VIII-2 SMP ISLAM NURUL IHSAN Palangka Raya yaitu Ketenagakerjaan dan permasalahanya, dalam proses pembelajaran bukan hanya teori saja yang di pelajari melainkan pemberian pengalaman langsung sebagai pelaku ekonomi agar peserta didik paham mengenai masalahmasalah ekonomi dalam kehidupan sehari-hari terutama didalam pasar, merupakan kegiatan ekonomi yang selalu di lakukan oleh setiap lapisan masayrakat. Standar komptensi (SK) dan Kompetensi Dasar (KD) IPS Ekonomi yang merupakan standar maksimal sebesar 70 yang yang harus di capai oleh peserta didik dan menjadi acuan dalam pegembagan kurikulum di setiap satuan pendidikan. Pencapain Standar Kompetrensi (SK) dan Kompetensi Dasar (KD) di dasarkan pada pemberdayaan peserta didik untuk membangun kemampuan, bekerja kelompok, dan pengetahuan sendiri.

Berdasarkan hasil observasi yang ditemui peneliti di lapangan pada saat observasi tepatnya di kelas VIII IPS-2 SMP ISLAM NURUL IHSAN Palangka Raya, bahwa pelaksanaan pembelajaran ekonomi masih terdapat permasalahan, terlihat peserta didik kurang memperhatikan penjelasan guru, hal ini dibuktikan dengan adanya peserta didik yang bersikap pasif dalam mengikuti pembelajaran ekonomi sehingga tidak mandiri dalam mengerjakan tugas individu dan peserta didik kurang aktif saat diskusi kelompok.

Selain itu sumber data yang didapatkan peneliti dari guru mata 
pelajaran IPS Ekonomi dari 30 peserta didik yang terdiri dari 12 peserta didik perempuan dan 18 peserta didik lakilaki, dari jumlah tersebut masih ada sebagian peserta didik yang belum mencapai KKM, dimana KKM untuk mata pelajaran IPS Ekonomi adalah 70. Adapun hasil belajar peserta didik yang belum tuntas yaitu dari 30 peserta didik hanya 13 atau $43,33 \%$ peserta didik yang mencapai Kriteria Ketuntasan Minimal (KKM) sementara 17 atau $56,67 \%$ peserta didik belum mencapai nilai Kriteria Ketuntasan Minimal (KKM) yang mana nilai Kriteria Ketuntasan Minimal (KKM) untuk mata pelajaran IPS Ekonomi adalah 70. Hal ini menandakan bahwa belum berhasilnya peserta didik dalam mata pelajaran IPS Ekonomi. Penelitian ini penting untuk dilakukan agar peserta didik aktif dalam proses pembelajar terutama dalam diskusi kelompok yang mana menekankan seluruh peserta didik aktif didalamnya. sehingga apa yang menjadi tujuan pendidikan bisa tercapai dan pada akhirnya akan melahirkan sumber daya manusia yang berkualitas.

\section{METODE PENELITIAN}

Metode penelitian merupakan hal yang menunjang bagi seorang peneliti untuk mendapatkan data yang valid bertujuan sebagai pendukung dalam masalah yang ditemukan, yang mana pada saatnya dapat digunakan untuk memahami, memecahkan suatu masalah yang terjadi dalam pendidikan. Pada penelitian ini, peneliti menggunakan metode Penelitian Tindakan Kelas (PTK), penelitian tindakan kelas memiliki peranan yang sangat penting dan trategis untuk mencapai suatu tujuan pendidikan, apabila diimplemetasikan dengan baik dan benar. Melalui tindakan kelas maka seorang guru akan bisa mengukur tingkat keberhasilan peserta didik.

Menurut Kunandar (2010:45) Penelitian Tindakan Kelas (PTK) terdiri dari tiga kata yaitu penelitian, tindakan, dan kelas.

1. Penelitian diartikan sebagai kegiatan mencermati suatu objek dengan menggunakan cara dan aturan atau metodologi ilmia dengan mengumpulkan data-data dan dianalisis untuk menyelesaikan suatu masalah.

2. Tindakan merupakan aktivitas yang sengaja di dilakukan dengan dengan tujuan tertentu yang berebetuk siklus kegiatan dengan tujuan untuk memperbaiki atau meningkatkan mutu atau kualitas proses belajar mengajar.

3. Kelas adalah sekelompok peserta didik yang dalam waktu yang sama menerima pelajaran dari seorang guru

Sedangkan Menurut Mulyasa (2011:11) berpendapat bahwa: Penelitian Tindakan Kelas (PTK) merupakan suatu upaya untuk menceramti kegiata belajar sekelompok peserta didik dengan memberikan sebuah tindakan (treatmen) yang sengaja dimunculkan. Tindakan tersebut dilakukan oleh guru bersama-sama dengan peserta didik, atau oleh peserta didik dibawah bimbingan dan arahan guru, dengan maksud untuk 
memperbaiki dan meningkatkan kualitas pembelajaran.

Dari beberapa pendapat di atas dapat disimpulkan bahwa penelitian tindakan kelas (PTK) merupakan suatu jenis penelitian yang dilakukan oleh guru dalam bentuk tindakan yang berupa kegiatan belajar mengajar yang bertujaan untuk memperbaiki kegiatan pembelajaran dan memecahkan permasalahan pembelajaran di kelas.

\section{HASIL DAN PEMBAHASAN}

Pembahasan hasil penelitian di kelas VIII IPS-2 SMP ISLAM NURUL IHSAN Palangka Raya tentang penggunaan model pembelajaran kooperatif tipe Co-op Co-op pada mata pelajaran IPS ekonomi adalah sebagai berikut :

1. Aktivitas Belajar Kelas VIII IPS-2 SMP ISLAM NURUL IHSAN Palangka Raya Baik Pada Saat Pembelajaran IPS Ekonomi Dengan Menggunakan Model Pemebelajaran Kooperatif Tipe Co-op Co-op. Berdasarkan analisis data yang dilakukan terhadap aktivitas peserta didik maka dapat diperoleh hasil aktivitas peserta didik pada setiap siklusnya. Pada Siklus I, aktivitas peserta didik memperoleh skor ratarata 3 dengan kriteria baik. Pada Siklus II aktivitas peserta didik memperoleh skor rata-rata 3 dengan kriteria baik. Hal ini menunjukkan bahwa aktivitas peserta didik baik pada saat pembelajaran IPS Ekonomi dengan menggunakan model pembelajaran kooperatif tipe Co-op Co-op. Motivasi dan keaktifan peserta didik dalam pembelajaran ekonomi dengan menerapkan model Cooperative Learning tipe Co-op Coop menjadi lebih aktif. Sebelum peneliti melakukan tindakan penenelitian tindakan kelas peserta didik memperoleh nilai ketuntasan $\quad 40,47 \% \quad$ kemudian setelah tindakan peserta didik memperoleh nilai ketuntasan 83,33\% pada siklus I dan dilanjutkan lagi di siklus II dengan ketuntasan $100 \%$. Hal ini menyatakan bahwa dengan menggunakan metode pembelajaran kooperatif dan memberikan motivasi kepada peserta didik pada saat pembelajaran akan meningkatkan hasil belajar peserta didik dan peserta didik lebih aktif dalam pembelajaran terutama pada saat pembelajaran dengan menggunakan metode kelompok.

2. Hasil Belajar IPS Ekonomi Peserta Didik Kelas VIII IPS-2 SMP ISLAM NURUL IHSAN Palangka Raya Dengan Model Pembelajaran Kooperatif Tipe Co-op Co-op. Berdasarkan analisis data yang dilakukan terhadap hasil belajar peserta didik, maka dapat diperoleh hasil belajar peserta didik dari tes awal (Pre Test), tes akhir Siklus I (Post Test) dan tes akhir Siklus II (Post Test). Pada tes awal, hasil belajar peserta didik memperoleh nilai rata-rata 44 (dibawah KKM ) dengan ketuntasan klasikal 23\% dengan kriteria kurang tercapai. Pada Siklus I hasil belajar peserta didik memperoleh nilai rata-rata 67 dengan ketuntasan klasikal 63\% dengan kriteria tidak tercapai. Pada Siklus II hasil belajar peserta didik 
meningkat dengan nilai rata-rata 87 dan ketuntasan klasikal 100\% dengan kriteria sangat tercapai. Berdasarkan hasil penelitian tersebut maka ada peningkatan hasil belajar IPS Ekonomi peserta didik dengan menggunakan model pembelajaran kooperatif tipe Co-op Co-op.

\section{SIMPULAN}

Berdasarkan hasil penelitian, maka dapat disimpulkan beberapa hal sebagai berikut :

1. Aktivitas belajar Peserta didik kelasVIII IPS-2 SMP Islam Nurul Ihsan Palangka Raya baik pada saat pembelajaran IPS ekonomi dengan menggunakan model pembelajaran kooperatif tipe Co-op Co-op. Pada Siklus I, aktivitas peserta didik memperoleh skor rata-rata 3 dengan kriteria baik. Kemudian pada Siklus II memperoleh skor rata-rata 3 dengan kriteria baik. Penggunaan model pembelajaran kooperatif tipe Co- op Co-op pada pembelajaran IPS ekonomi melibatkan peserta didik secara aktif dalam proses pembelajaran.

2. Ada peningkatan hasil belajar IPS ekonomi peserta didik kelas VIII IPS-2 SMP IslamNurul Ihsan Palangka Raya lebih aktif pada saat pembelajaran IPS ekonomi dengan menggunakan model pembelajaran kooperatif tipe Co-op Co-op. Pada tes awal (pre test) hasil belajar peserta didik memperoleh nilai ratarata 44 dengan ketuntasan klasikal 23\% Pada Siklus I hasil belajar peserta didik memperoleh nilai ratarata 67 dengan ketuntasan klasikal 63\% dan di Siklus II hasil belajar peserta didik memperoleh nilai ratarata 87 dengan ketuntasan klasikal $100 \%$.

\section{DAFTAR PUSTAKA}

Ahmad Susanto. (2013). Teori Belajar Dan Pembelajaran Di Sekolah Dasar. Jakarta: Kencana Prenada Media Group

Dalyono. (2010). Psikologi Pendidikan. Jakarta : Rineka Cipta

Depdiknas, (2003). Undang-Undang Nomor 20 Tahun 2003 Tentang Sistem Pendidikan Nasional. Jakarta : Sekretariat Negara.

Kunandar. 2010. Penelitian Tindakan Kelas. Jakarta: Rajawali Pers

Mulyasa. 2011. Praktik Penelitian Tindakan Kelas. Bandung: Remaja Rosda Karya.

Ngalim Purwanto. (2014). Psikologi Pendidikan. Jakarta: Remaja Rosda Karya

Sardiman. (2014). Interaksi dan Motivasi Belajar-Mengajar. Jakarta: Rajawali Pers 